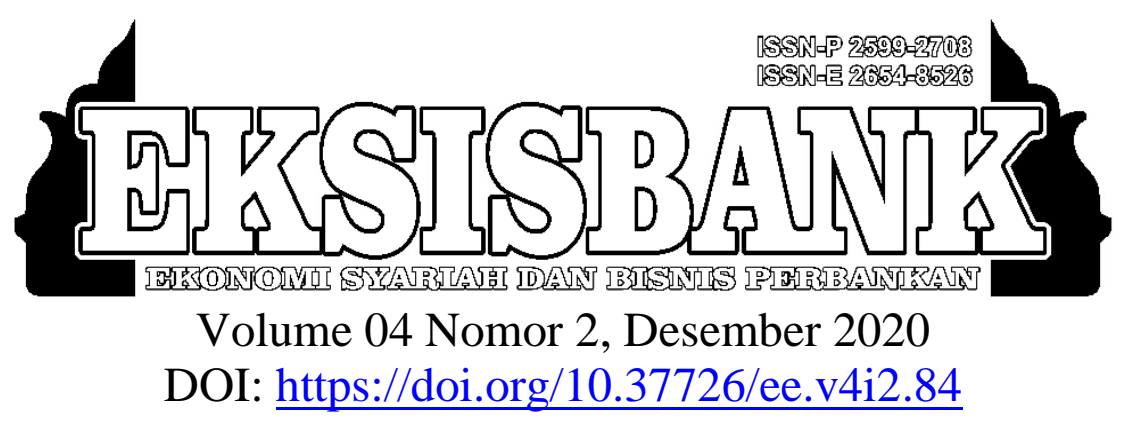

\title{
Analisis Faktor Yang Mempengaruhi Masyarakat Muslim Menggunakan Jasa "Bank Emok" Di Desa Cilalawi Kecamatan Sukatani Kabupaten Purwakarta
}

\author{
Lisa Dewi Angggraeni ${ }^{1}$, M. Cahyo Sucipto ${ }^{2}$, Siti Rohmat ${ }^{3}$ \\ ${ }^{1,2,3}$ Sekolah Tinggi Ilmu Ekonomi Syariah (STIES) Indonesia Purwakarta \\ ${ }^{1}$ lisadewianggraeni8431@ gmail.com \\ 2m.cahyosucipto@sties-purwakarta.ac.id \\ sitirohmat@sties-purwakarta.ac.id
}

\begin{abstract}
ABSTRAK
Masyarakat Desa Cilalawi Kecamatan Sukatani Kabupaten Purwakarta selama ini memanfaatkan pinjaman rentenir atau disana dikenal dengan sebutan "Bank Emok" untuk memenuhi kebutuhan konsumtif, karena dengan pekerjaan mereka yang penghasilannya tidak menentu belum bisa memenuhi kebutuhan atau keperluannya dengan cepat. Namun tidak sedikit juga masyarakat memanfaatkan jasa "Bank Emok" itu untuk hal yang bersifat produktif, yaitu sebagai modal usaha. Tujuan penelitian ini adalah untuk mengetahui antusiasme masyarakat muslim di Desa Cilalawi Desa Cilalawi Kecamatan Sukatani Kabupaten Purwakarta terhadap keberadaan "Bank Emok". Untuk mengetahui faktor-faktor apa saja yang mempengaruhi masyarakat muslim di Desa Cilalawi Kecamatan Sukatani Kabupaten Purwakarta menggunakan jasa "Bank Emok". Metode penelitian yang digunakan dalam penelitian ini adalah melalui pendekatan kualitatif atau pendekatan naturalistik. karena sifat data yang dikumpulkan bercorak kualitatif, bukan kuantitatif, naturalistik karena situasi lapangan penelitian bersifat natural atau wajar, sebagaimana adanya, tanpa dimanipulasi, dan tanpa diatur dengan eksperimen atau tes. Penelitian naturalistik melihat situasi nyata yang berubah secara alamiah, terbuka, tidak ada rekayasa pengontrolan variabel. Teknik pengumpulan data yang digunakan dalam penelitian ini terdiri dari Dokumentasi dan wawancara. Hasil penelitian menunjukkan bahwa antusiasme masyarakat dalam menggunakan jasa Bank Emok cukup besar. Rata-rata dalam satu Bank Emok memiliki jumlah nasabah lebih dari sepuluh orang bahkan ada yang sampai 40 orang. Antusiasme masyarakat juga terlihat dari jumlah Bank Emok yang dipinjam. Sebagian besar masyarakat meminjam lebih dari satu Bank Emok bahkan ada yang sampai empat Bank
\end{abstract}

EKSISBANK (Ekonomi Syariah dan Bisnis Perbankan), Volume 4, Nomor 2, Desember 2020 
Emok sekaligus. Masyarakat Desa Cilalawi menggunakan jasa Bank Emok dipengaruhi faktor internal yang meliputi pribadi seperti usia, situasi ekonomi, pekerjaan, gaya hidup dan psikologis seperti motivasi, persepsi dan sikap masyarakat. Faktor eksternal yang mempengaruhi masyarakat Desa Cilalawi dalam menggunakan jasa Bank Emok adalah budaya, sosial, dan pemasaran.

Kata Kunci: Masyarakat Muslim, Jasa, Bank Emok

\section{ABTRACT}

The people of Cilalawi Village, Sukatani District, Purwakarta Regency have been using loan sharks or there is what is known as "Bank Emok" to meet consumptive needs, because with their jobs whose income is uncertain, they cannot meet their needs or needs quickly. However, not a few people also use the "Emok Bank" service for productive things, namely as business capital. The purpose of this study was to determine the enthusiasm of the Muslim community in Cilalawi Village, Cilalawi Village, Sukatani District, Purwakarta Regency towards the existence of "Bank Emok". To find out what factors influence the Muslim community in Cilalawi Village, Sukatani District, Purwakarta Regency, use the service of "Bank Emok". The research method used in this research is through a qualitative approach or a naturalistic approach. because the nature of the data collected is qualitative, not quantitative, naturalistic because the situation in the research field is natural or natural, as it is, without being manipulated, and without being regulated by experiments or tests. Naturalistic research looks at real situations that change naturally, openly, there is no engineering variable control. The data collection techniques used in this study consisted of documentation and interviews. The results showed that the enthusiasm of the community in using Bank Emok services was quite large. On average, one Emok Bank has more than ten customers and some even up to 40 people. The enthusiasm of the community can also be seen from the number of Bank Emok borrowed. Most people borrow more than one Emok Bank and some even up to four Emok Banks at once. The people of Cilalawi Village use Bank Emok services which are influenced by internal factors including personal factors such as age, economic situation, occupation, lifestyle and psychology such as motivation, perceptions and attitudes of the community. External factors that influence the people of Cilalawi Village in using Bank Emok services are culture, social, and marketing.

Keyword: Moslem Society, Services, Bank Emok

\section{PENDAhUluan}

Kemiskinan adalah keadaan dimana terjadi ketidakmampuan untuk memenuhi kebutuhan dasar seperti makanan, tempat berlindung, pendidikan, dan kesehatan. Kemiskinan disebabkan oleh kelangkaan alat pemenuh kebutuhan dasar, ataupun sulitnya akses terhadap pendidikan dan pekerjaan. Kemiskinan merupakan masalah global. Sebagian orang memahami istilah ini secara subyektif dan komparatif, sementara yang lainnya melihat dari segi moral dan evaluatif, dan yang lainnya melihat dari segi moral dan evaluatif dan yang lainnya lagi memahaminya dari sudut ilmiah yang telah mapan.

Kemiskinan telah menjadi isu sosial sekaligus isu politik yang banyak dibicarakan oleh berbagai kalangan, baik kaum politisi, cendikiawan maupun mereka yang bergerak dalam LSM-LSM. Di pihak pemerintah sendiri, berbagai strategi dan upaya terus dikembangkan untuk segera mengurangi 
kesenjangan dan membebaskan masyarakat dari belenggu kemiskinan, terutama masyarakat miskin yang tinggal di daerah pedesaan. Apa yang sudah kita alami selama ini menyadarkan kita bahwa yang diperlukan bagi pengentasan masyarakat dari kemiskinan bukan cuma paket bantuan ekonomi atau upaya-upaya yang bersifat kemurahan hati saja. Tetapi lebih penting dari itu adalah upaya-upaya pemberdayaan masyarakat.

Grafik 1.1

Garis Kemiskinan (rupiah/kapita/bulan)

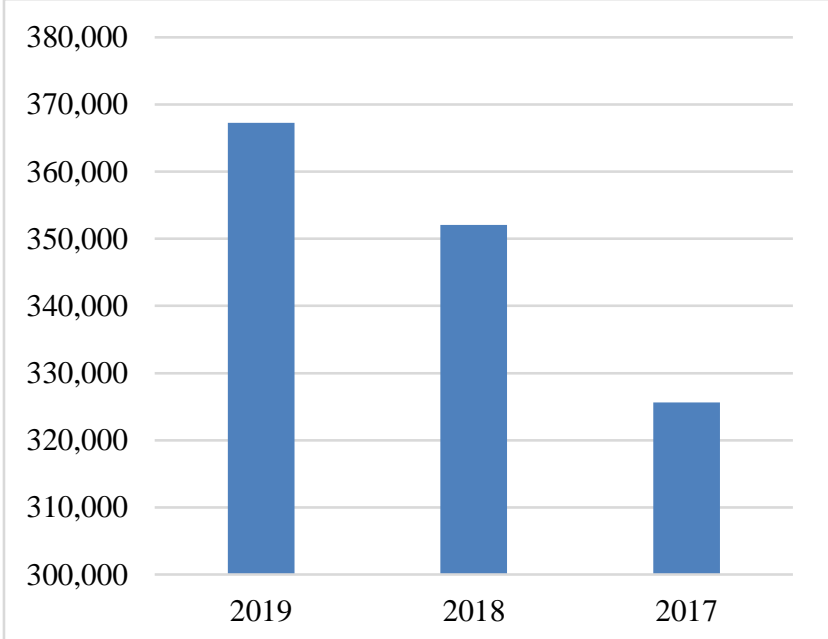

Sumber : BPS Kab. Purwakarta

Grafik 1.2

Jumlah Penduduk Miskin (ribu)

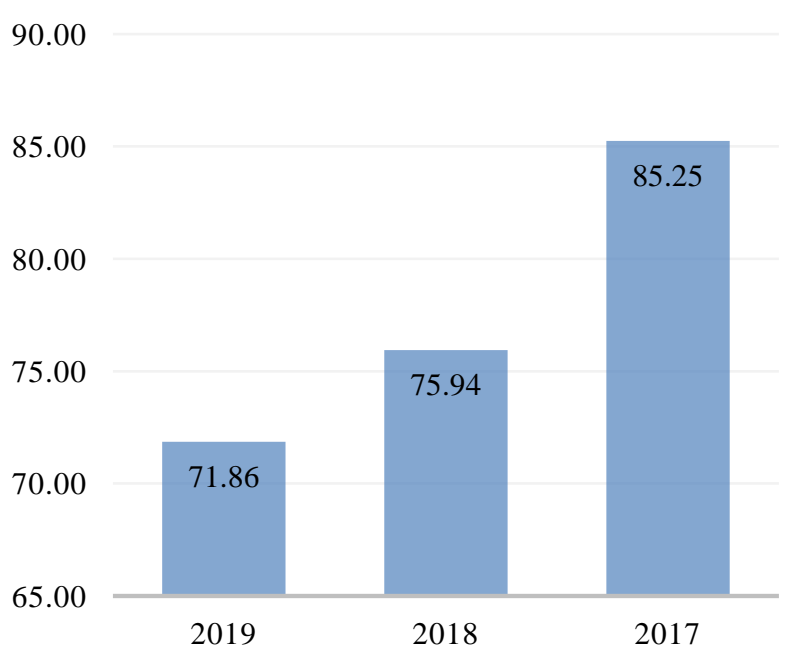

Sumber : BPS Kab. Purwakarta
Grafik 1.3

Persentase Penduduk Miskin

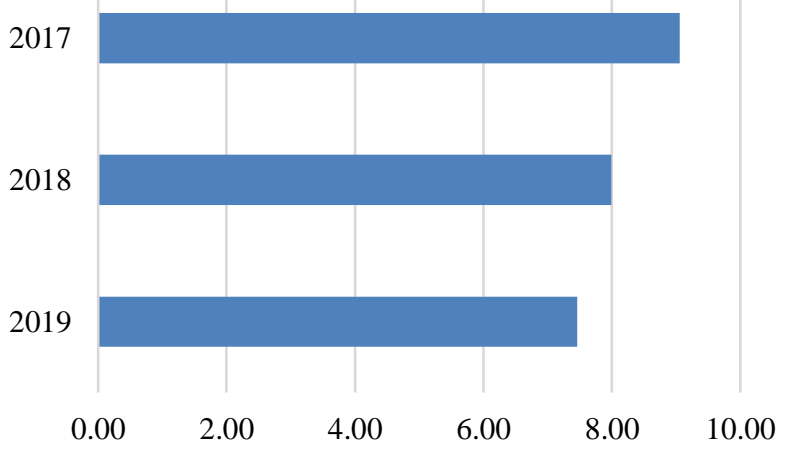

Sumber : BPS Kab. Purwakarta

Upaya pemberdayaan ini tidak lain adalah kebijakan yang memberi ruang gerak, fasilitas publik dan kesempatan yang kondusif bagi masyarakat miskin untuk mengentaskan diri mereka sendiri (Suyanto 2013).

Seiring dengan kebutuhan masyarakat yang semakin banyak dan mendesak, dengan tidak diimbangi oleh ekonomi yang baik maka muncullah badan-badan penyedia jasa pinjaman keuangan: pegadaian, bank konvensional, dan badan penyedia jasa pinjaman lainnya. Dengan berbagai macam penawaran peminjaman uang yang tentunya menggiurkan bagi masyarakat untuk mendapatkan uang dengan cara cepat dan mudah.

Sudah bukan hal yang tabu lagi apabila penyedia jasa pinjam keuangan meminjamkan uangnya dengan menerapkan bunga, walaupun terkadang bunga tersebut tergolong besar. Sebagian masyarakat terkadang tidak memperdulikan seberapa banyak bunga yang ditetapkan oleh penyedia jasa. Karena bagi mereka yang penting mendapatkan uang dengan cara cepat dan mudah.

Hutang-piutang yang dilakukan oleh masyarakat Kampung Cilalawi Kecamatan Sukatani Kabupaten Purwakarta selama ini adalah hutang-piutang yang mengandung unsur riba. Bahkan sebagian masyarakat

EKSISBANK (Ekonomi Syariah dan Bisnis Perbankan), Volume 4, Nomor 2, Desember 2020 
memanfaatkan pinjaman itu hanya untuk memenuhi kebutuhan konsumtif, karena dengan pekerjaan mereka yang penghasilannya tidak menentu belum bisa memenuhi kebutuhan atau keperluannya dengan cepat. Dengan berhutang mereka bisa memenuhi tersebut dan mencicil hutangnya dari hasil kerja mereka. Namun tidak sedikit juga masyarakat memanfaatkan hutangnya untuk hal yang bersifat produktif, yaitu untuk menjadikannya modal usaha.

Masyarakat yang memanfatkan hutang untuk hal konsumtif, dikhawatirkan akan menjadi sebuah kebiasaan yang berkepanjangan bahkan menjadi keharusan bagi mereka. Apabila sudah menjadi kebiasaan seperti itu, ditakutkan bisa membuat generasi selanjutnya melakukan hal yang sama dan seterusnya akan tercipta kebudayaan yang buruk yang akan sulit untuk dihilangkan.

Globalisasi telah melahirkan apa yang disebut sebagai budaya massa yang terwujud secara nyata berupa tumbuhnya budaya konsumerisme di kalangan masyarakat. Budaya ini telah meruntuhkan akal sehat manusia tidak lagi dapat membedakan antara keinginan (want) dan kebutuhan (need).

Konsumsi (konsumerisme) adalah perspektif sosiologi dengan demikian jelas bukan sekedar pemenuhan kebutuhan fisik, melainkan yang lebih utama adalah pemenuhan kebutuhan sosial berupa status sosial tinggi dengan memiliki barang-barang tertentu atau mengkonsumsi jasa mewah lainnya (Haryanto 2017).

Selama ini berhutang sudah menjadi kebiasaan dalam kehidupan sehari-hari masyarakat kampung Cilalawi. Akan tetapi dilihat dari realitasnya, sebagian masyarakat yang terbiasa berhutang belum mempunyai tanda-tanda sejahtera dalam kehidupannya, bahkan terlihat sebaliknya dengan terlilit hutang.
Sejauh yang penulis amati dari kebiasaan masyarakat dalam berhutang bahwa realitasnya masih cukup banyak masyarakat yang belum paham terhadap hukumnya dan masih belum merasakan kesejahteraan dalam hidupnya, khususnya dalam segi ekonomi. Dari uraian ini melandasi penulis untuk melakukan penelitian tentang kebiasaan masyarakat dalam berhutang dengan melihat faktor-faktor yang mempengaruhi masyarakat dalam menggunakan jasa "Bank Emok".

Uraian di atas, terlihat adanya suatu permasalahan yang menarik untuk dikaji lebih lanjut tentang perilaku masyarakat khususnya masyarakat muslim dalam menggunakan jasa "Bank Emok", dan penulis akan mengangkat judul penelitian: "Analisis Faktor Yang Mempengaruhi Masyarakat Muslim Untuk Menggunakan Jasa "Bank Emok" (Studi Kasus Kampung Cilalawi Desa Cilalawi Kecamatan Sukatani Kabupaten Purwakarta)."

Adapun focus permasalahan pada penelitian ini adalah untuk mengetahui antusiasme masyarakat muslim di Kampung Cilalawi Desa Cilalawi Kecamatan Sukatani Kabupaten Purwakarta terhadap keberadaan "Bank Emok"; dan Faktor-faktor apa saja yang mempengaruhi masyarakat muslim di Kampung Cilalawi Desa Cilalawi Kecamatan Sukatani Kabupaten Purwakarta menggunakan jasa "Bank Emok".

Manusia dalam memenuhi kebutuhan hidupnya tidak dapat dipenuhi dengan harta sendiri, maka manusia dapat memenuhi kebutuhannya tersebut dengan cara meminjham atau berhutang, baik meminjam kepada bank, meminjam kepada koperasi atau meminjam kepada sesamanya. Karena dalam melakukan peminjaman ini agama Islam sudah mengakui keabsahannya.

Hukum hutang-piutang fleksibel tergantung situasi kondisi dan toleransi. Pada umumnya hutang-piutang hukumnya sunah 
bila dalam keadaan normal, hukumnya haram apabila meminjam uang untuk membeli miras, narkoba, berbuat kejahatan, dan sebagainya. Hukumnya wajib jika memberikan kepada orang yang sangat membutuhkan seperti tetangga yang anaknya sedang sakit keras.

Moh. Hatta dalam memandang tentang riba dan status bunga Bank, lebih menekankan pinjaman itu digunakan untuk apa dan melihat riba yang terjadi di jaman jahiliah. Di mana pada waktu itu orang yang meminjam uang biasanya untuk keperluan hidupnya, dan pinjaman inilah yang disebut pinjaman konsumtif.

Moh. Hatta menghukumi riba pada pinjaman konsumtif, karena beliau melihat bahwa dari segi ekonomi cara riba merupakan jalan usaha yang tidak sehat, sebab keuntungan yang diambil dari kreditur bukan dari usaha yang produktif. Dari sosial masyarakat tidak dapat mengambilkan keuntungan sedikitpun dari praktek riba. Sebab riba tidak akan pernah menambah kekayaan sesuatupun pada masyarakat atau kemampuan mengangkat ekonomi, bahkan sebaliknya riba hanya akan menambah penderitaan yang parah. Untuk menguatkan pandangannya bahwa pinjaman konsumtif merupakan riba, beliau juga melihat bahwa pinjaman inilah yang terjadi pada zaman dahulu, dan tidak ada fakta yang menunjukkan bahwa itu untuk berusaha (Hatta 2008).

Manajer pemasaran yang mempelajari perilaku masyarakat selaku konsumen (perilaku konsumen) akan mengetahui kegiatan pemasaran yang telah ada maupun kesempatan yang yang belum terpenuhi kebutuhannya serta dapat mengidentifikasikan untuk mengadakan segmentasi pasar. Perilaku konsumen yang berbeda-beda dalam memenuhi kebutuhan dan keinginannya perlu dipelajari sehingga perusahaan dapat menentukan harga, mengembangkan produk, menentukan distribusi dan sarana promosi yang tepat. Perilaku konsumen yang berbedabeda itu dipengaruhi oleh beberapa faktor. Pembelian konsumen sangat dipengaruhi oleh faktor-faktor kultural, sosial, pribadi, dan psikologis (Kotler and Amstrong 2007).

Faktor-faktor yang mempengaruhi perilaku konsumen dapat dilihat dari segi eksternal dan internal. Faktor eksternal adalah faktor-faktor yang berasal dari lingkungan eksternal individu yang sangat berpengaruh terhadap perilaku konsumen. Yang termasuk faktor eksternal adalah budaya, sosial, dan pemasaran.

\section{Faktor Budaya}

Pada setiap kelompok masyarakat pasti memiliki budaya, dimana budaya tersebut bisa digunakan sebagai aturan, kebiasaan dan ciri khas dari suatu kelompok masyarakat. Faktor budaya terdiri dari budaya meliputi, sub budaya dan kelas sosial merupakan hal yang sangat penting dalam perilaku konsumen. a. Budaya

Budaya adalah kumpulan nilai-nilai dasar, persepsi, keinginan dan perilaku yang dipelajari dari anggota suatu masyarakat dari keluarga dan lembaga penting lainnya.

\section{b. Sub Budaya}

Setiap kebudayaan mengandung subkebudayaan yang lebih kecil atau kelompok orang-orang yang mempunyai sistem nilai yang sama berdasarkan pengalaman dan situasi kehidupan yang sama. Sub kebudayaan meliputi kewarganegaraan, agama, kelompok ras dan daerah geografis. Sub-Budaya adalah sekelompok orang yang mempunyai sistem nilai sama berdasarkan pada pengalaman hidup dan situasi.

c. Kelas Sosial

Adalah bagian-bagian yang relatif homogen dan tetap dalam suatu masyarakat yang tersusun secara hirarki dan anggotaanggotanya memiliki tata nilai, minat dan perilaku serupa (Kotler and Amstrong 2007).

\section{Faktor Sosial}


Selain faktor budaya, perilaku seorang konsumen dipengaruhi oleh beberapa faktor sosial, antara lain :

a. Kelompok Acuan

Perilaku konsumen umumnya dipengaruhi oleh individu lainnya, individu yang mempengaruhi tersebut dapat dimasukkan sebagai kelompok primer yang terdiri atas kelompok terdekat dari individu tersebut. Misalnya ; keluarga, teman dan tetangga, sedangkan kelompok kedua adalah kelompok sekunder yang mempunyai interaksi yang lebih formal dan memiliki sedikit interaksi. Kelompok sekunder meliputi kelompok keagamaan, serikat buruh.

b. Keluarga

Keluarga adalah kelompok yang terdiri dari dua atau lebih orang yang berhubungan melalui darah, perkawinan ataupun adopsi dan tinggal bersama. Anggota keluarga sangat mempengaruhi dalam pengambilan keputusan pembelian terhadap individu, keluarga mempunyai peran penting dimana setiap anggota keluarga saling mempengaruhi.

c. Peran dan Status

Dalam kehidupan bermasyarakat, peran dan status selalu mengikuti perjalanan setiap individu. Peran dan status seorang individu dalam kelompok tertentu misalnya keluarga sangat mempengaruhi individu tersebut dalam perilaku pembelian (Kotler and Amstrong 2007).

\section{Faktor Pemasaran}

\section{a. Produk}

Produk adalah segala sesuatu yang dapat ditawarkan ke pasar untuk memenuhi kebutuhan dan keinginan konsumen. Pengertian produk secara umum juga dikemukakan oleh beberapa para ahli. Menurut Philip Kotler produk adalah segala sesuatu yang bisa ditawarkan kepada sebuah pasar agar diperhatikan, diminta, dipakai, atau dikonsumsi sehingga mungkin memuaskan keinginan atau kebutuhan. b. Pemasaran

Pemasaran adalah keinginan manusia yang bertujuan untuk memuaskan kebutuhan dan keinginan langganan melalui proses pertukaran dan pihak-pihak yang berkepentingan dengan perusahaan. Pemasaran adalah kegiatan perusahaan dalam membuat rencana, menentukan harga, promosi, serta mendistribusikan barang dan jasa.

\section{c. Promosi}

Promosi adalah semua jenis kegiatan pemasaran yang ditujukan untuk mendorong permintaan konsumen atas produk yang ditawarkan produsen atau penjual. Tujuan promosi adalah : 1) Memodifikasi tingkahlaku konsumen, 2) Memberitahukan /menginformasikan produk kepada konsumen, 3) Membujuk dan memotivasi konsumen agar mau membeli produk yang ditawarkan, dan 4) mengingatkan konsumen tentang produk agar tidak beralih ke produk lain. Promosi dalam sistem ekonomi syariah harus memperhatikan nilai-nilai kejujuran dan menjauhi penipuan. Media atau sarana dan metode yang digunakan harus sesuai dengan pinsip Syariah (Suryani 2008).

Sedangkan dari faktor internal adalah faktor-faktor yang berasal dari lingkungan internal yang berpengaruh terhadap perilaku konsumen terdiri dari :

\section{Faktor Pribadi}

Dalam perilaku pembelian, faktor pribadi juga memengaruhi seorang individu. Faktor tersebut terdiri dari:

a. Usia

Dalam kehidupan, perjalanan usia tidak dapat dihindarkan. Dengan berjalannya usia maka terjadi perubahan pola konsumsi masing-masing usia.

b. Pekerjaan

Pekerjaan juga dapat mempengaruhi seorang individu dalam perilaku konsumsinya, misalkan seorang pekerja kasar maka 
akan cenderung membeli pakaian untuk pekerjaan kasar, sedangkan pekerja kantoran akan cenderung untuk membeli stelan kemeja atau jas.

\section{c. Situasi Ekonomi}

Dalam perilaku pembelian, sedikit banyak juga dipengaruhi oleh situasi ekonomi, dengan berubahnya situasi ekonomi maka biasanya akan merubah perilaku konsumen dalam melakukan pembelian.

d. Gaya Hidup

Individu dengan latar belakang gaya hidup yang berbeda memiliki kecenderungan berbeda pula dalam perilaku pembeliannya. Gaya hidup dapat dipengaruhi oleh keluarga, situasi pekerjaan, hobi, dan yang lainnya.

e. Kepribadian dan Konsep Diri

Kepribadian adalah karakteristik psikologis yang berbeda dari seseorang yang menyebabkan tanggapan yang relatif konsisten dan tetap terhadap lingkungannya. kepribadian dapat menjadi variabel yang sangat berguna dalam menganalisis perilaku konsumen, asalkan jenis kepribadian tersebut dapat diklasifikasikan dengan akurat dan terdapat korelasi yang kuat antara jenis kepribadian tertentu dengan pilihan produk atau merek. Yang juga berkaitan dengan kepribadian adalah konsep diri seseorang. Konsep diri adalah cara pandang konsumen terhadap dirinya sendiri. Dengan mengetahui konsep diri seseorang pemasar akan mengetahui tujuan pembelian bagi konsumen.

\section{Faktor Psikologis}

Faktor psikologis adalah salah satu faktor yang cukup dominan dalam menentukan proses keputusan pembelian, sebab pola konsumsi seseorang juga dipengaruhi oleh daur hidup keluarga dan kepribadiannya. Faktor psikologis mencakup persepsi, motivasi, pembelajaran, sikap dan kepribadian. Sikap dan kepercayaan merupakan faktor psikologis yang mempengaruhi keputusan pembelian konsumen. Pilihan pembelian seseorang dipengaruhi oleh empat faktor psikologis utama:

a. Motivasi

Seorang individu dalam kehidupan bermasyarakat juga memerlukan motivasi untuk menjalani hidupnya, motivasi sendiri juga dapat mempengaruhi individu dalam melakukan perilaku pembelian.

b. Persepsi

Setiap hari individu mempunyai motivasi untuk melakukan pembelian, tetapi faktor lain yang mempengaruhi seorang individu tersebut adalah persepsi. Persepsi merupakan rangsangan yang tereliminasi, terorganisir dan teranalisa. Sering kali seorang individu dihadapkan pada suatu pilihan, dalam pemilihan suatu barang misalnya, dengan adanya persepsi maka seorang individu dapat memilih sesuai dengan persepsi yang tertanam dalam dirinya.

c. Proses belajar

Dalam melakukan tindakan seorang individu tidak lepas dari pembelajaran, perubahan perilaku individu dalam pembelian juga dipengaruhi oleh pengalaman dan pembelajaran dari pembelian sebelumnya. Ahli teori ilmu pengetahuan mengatakan bahwa pengetahuan seseorang dihasilkan melalui suatu proses yang paling mempengaruhi dari dorongan, rangsangan, petunjuk, tanggapan dan penguatan.

d. Keyakinan dan sikap

Seorang pemasar biasanya memerhatikan keyakinan konsumennya akan produknya, sering kali seorang pemasar harus merubah iklannya untuk membentuk keyakinan individu dalam pemilihan suatu produk (Hernawati and Hasanah 2019).

\section{TINJAUAN PUSTAKA}

Penelitian tentang Analisis Faktor Yang Mempengaruhi Masyarakat Muslim Menggunakan Jasa "Bank Emok" sudah 
banyak dilakukan oleh peneliti sebelumnya, tapi tentu saja mempunyai perbedaanperbedaan antara penelitian ini dengan penelitian sebelumnya. Berikut adalah penelitian sebelumnya yang meneliti tentang Analisis Faktor Yang Mempengaruhi Masyarakat Muslim Menggunakan Jasa "Bank Emok" Di Desa Cilalawi Kecamatan Sukatani Kabupaten Purwakarta;

1. Penerapan Infak sebagai Program Pengurangan Ketergantungan Masyarakat terhadap Rentenir (Studi Kasus pada BAZNAS Kabupaten Ngawi) (Az-zarqa and Hidayah 2018)

Lembaga zakat mengambil peran penting dalam meningkatkan kondisi ekonomi masyarakat kurang mampu. Lembaga zakat bekerja untuk mencapai tujuan yang lebih luas, tidak hanya membentuk dasar jaminan sosial saat ini, tetapi juga membawa keuntungan lain pada masyarakat. Badan Amil Zakat Kabupaten Ngawi misalnya, dalam merespon maraknya praktik rentenir yang tersebar di Kabupaten Ngawi hadir dengan programnya, menjadikan infak sebagai program pengurangan ketergantungan masyarakat terhadap rentenir. Atas dasar itulah peneliti tertarik untuk meneliti bagaimana kebijakan BAZNAS kabupaten Ngawi melalui infak sebagai program pengurangan ketergantungan masyarakat terhadap rentenir dan bagaimana efektivitas infak sebagai program pengurangan ketergantungan masyarakat terhadap rentenir pada BAZNAS Kabupaten Ngawi ditinjau dari sosiologi hukum Islam.

Hasil penelitian ini menunjukkan bahwa kebijakan BAZNAS Kabupaten Ngawi melalui infak sebagai program pengurangan ketergantungan masyarakat terhadap rentenir menggunakan strategi yaitu dengan memberikan pinjaman tanpa bunga, tanpa jaminan, dan tanpa potongan, diangsur dengan batas waktu maksimal 10 bulan. Kebijakan
BAZNAS selanjutnya yaitu membuat model dengan membentuk kelompok. Untuk melihat efektivitas apakah masyarakat kembali kepada rentenir setelah mendapatkan pinjaman BAZNAS, ditinjau dari sosiologi hukum Islam, menggunakan beberapa indikator. Pertama, pilihan rasional, masyarakat memilih pinjaman BAZNAS dari pada memilih jasa rentenir. kedua, tindakan sosial Max Weber, masyarakat dalam tindakannya termasuk ke dalam tipologi rasionalitas instrumental dan rasionalitas nilai. Dalam tinjauan sosiologi hukum Islam, termasuk ke dalam pengaruh hukum Islam terhadap perubahan masyarakat. Dari 53\% masyarakat yang mendapatkan program BAZNAS untuk membayar utang rentenir, respon $28,4 \%$ diantaranya mengatakan berusaha melepas rentenir. Hal itu berarti sudah terdapat pengaruh, namun belum maksimal. Respon $28,4 \%$ tersebut menunjukkan bahwa segala strategi dan model yang ditawarkan BAZNAS kurang efektif untuk mengurangi ketergantungan masyarakat terhadap rentenir karena dana yang dipinjamkan dirasa kurang mencukupi dan tidak adanya tim dakwah BAZNAS yang memberikan pembinaan kepada masyarakat secara rutin.

2. Faktor-Faktor Yang Mempengaruhi Masyarakat Berhubungan Dengan Rentenir (Novida and Dahlan 2020)

Penelitian ini dilakukan untuk mengetahui lebih dalam, dan menganalisis faktor-faktor apa saja yang mempengaruhi masyarakat desa terkait rentenir sehingga ke depannya tidak ada lagi masyarakat desa yang berurusan dengan rentenier. Tetapi mereka lebih cenderung memilih bank yang merupakan bank konvensional dan bank syariah. Metode penelitian yang digunakan adalah dengan melakukan wawancara langsung dan menyebarkan kuesioner kepada masyarakat 
desa tempat peneliti melakukan penelitian. Teknik analisis data dengan regresi berganda dengan program SPSS Versi 22. Hasil penelitian menunjukkan bahwa faktor kebutuhan, faktor agama, faktor jaminan dan faktor kemudahan yang berpengaruh signifikan terhadap masyarakat berhubungan dengan rententir baik secara parsial maupun simultan.

3. Analisis faktor eksternal yang dipertimbangkan masyarakat muslim pesisir Tuban untuk mengunakan layanan Bank Thithil (Syaifudin and Ekawaty 2019)

Bank Thithil adalah lembaga keuangan informal yang menawarkan layanan pinjaman berbunga tinggi kepada publik. Penelitian ini bertujuan untuk mengetahui faktor-faktor eksternal yang menjadi pertimbangan masyarakat muslim pesisir dalam menggunakan jasa keuangan sampai dengan bank. Pengumpulan data dilakukan melalui survei dengan kuesioner dan wawancara mendalam kepada nasabah bank di Desa Bulu Meduro Kabupaten Tuban dan dianalisis dengan metode analisis faktor eksplorasi. Hasil penelitian menunjukkan bahwa terdapat delapan faktor eksternal yang menjadi pertimbangan nasabah dalam menggunakan jasa bank, yaitu: faktor kompensasi dan aksesibilitas kredit, paritas dan layanan nasabah, fleksibilitas waktu transaksi, kemudahan administrasi, citra merek, keunggulan lokasi, keunggulan anggota, dan terbatasnya cakupan kelembagaan keuangan syariah. Dari hasil analisis faktor eksternal yang kemudian dianalisis secara mendalam menggunakan wawancara dengan beberapa nasabah ditemukan bahwa terdapat dua faktor yang menjadi penarik kuat masyarakat muslim untuk menggunakan jasa bank thithil, yaitu faktor pelayanan prima bank sampai dengan dan hambatannya. lembaga keuangan syariah.

\section{Dampak Kredit Rentenir Terhadap} Keuntungan Usaha Pagandeng Sayur Di Kecamatan Pallangga Kabupaten Gowo (Rusydi and Rasulong 2009)

Penelitian bertujuan menguji hipotesis dari variabel-variabel yang mempengaruhi variabel pinjaman pagandeng sayur. Mengetahui seberapa besar pengaruh Kentungan Bersih per bulan (dalam \%) terhadap pinjaman pagandeng sayur. mengetahui seberapa besar pengaruh Bunga Pinjaman per bulan (dalam \%) terhadap pinjaman pagandeng sayur. Penentuan sampel dilakukan dengan metode Purposive Random Sampling. Jumlah sampel dalam penelitian ini sebanyak 50 responden Pagandeng Sayur yang terdapat di dua titik pangkalan utama yaitu Pangkalan Panciro dan Pangkalan Cambaya. Dalam membuktikan hubungan variabel secara kuantitatif, peneliti menggunakan pendekatan ekonometrik yang berupa Analisa Regresi dan Korelasi. Kesimpulan hasil penelitian adalah variabel tingkat keuntungan sangat berpengaruh dalam menentukan besarnya jumlah pinjaman. Adapun variabel tingkat bunga dalam penelitian ini kurang berperan dalam menentukan besarnya jumlah pinjaman karena meskipun tingkat bunga pinjaman per bulan relatif tinggi, para pagandeng sayur tetap melakukan pinjaman kepada rentenir.

5. Optimalisasi Peran Bmt Dalam Upaya Penghapusan Praktik Rentenir (Ayogi and Kurnia 2015)

Tenaga Keberadaan rentenir semakin eksis hingga saat ini, hal ini dibuktikan dengan fakta bahwa 70\% UMKM terjerat rentenir. Praktik seperti itu jelas harus ditiadakan di masyarakat karena berdampak negatif bagi masyarakat. Oleh karena itu, keberadaan Baitul Maal wa tamwil (BMT) sebagai 
lembaga keuangan mikro yang dijalankan dengan prinsip syariah dinilai sangat penting untuk menghilangkan praktik rentenir di masyarakat. Tujuan dari penelitian ini adalah untuk mengetahui peran yang telah dilakukan BMT dalam upaya penghapusan praktik rentenir dan untuk mengetahui peran yang dimainkan oleh BMT secara optimal atau tidak dalam upaya penghapusan praktik rentenir. Pengumpulan data menggunakan analisis deskriptif kuantitatif melalui wawancara. Pengolahan data dilakukan dengan menggunakan pemrograman lnear, dengan bantuan program aplikasi LINDO, untuk melengkapi pemodelan matematis digunakan untuk mengoptimalkan suatu tujuan dengan berbagai kendala. Kemudian dianalisis dengan analisis primal, dual, dan sensitivitas. Kesimpulan dari penelitian ini adalah peran yang dilakukan oleh BMT Amal Atina dan BMT Berkah Mandiri Sejahtera dalam upaya menghilangkan praktik rentenir belum optimal, karena sumber daya yang digunakan dapat meminimalkan. Praktik rentenir atau rentenir di masyarakat masih belum dimanfaatkan secara maksimal.

6. Pembebasan Nasabah Dari Rentenir Studi Kasus Baitul Maal Wa Tamwil (BMT) Almaun Berkah Madani (Drasmawita and Herianingrum 2020)

Penelitian ini bertujuan untuk mengetahui peran BMT Almaun Berkah Madani dalam membantu nasabah dari perangkap rentenir. BMT ini juga diharapkan dapat mengurangi kecemasan sebagian orang yang memiliki keterbatasan finansial. Pendekatan penelitian ini adalah kualitatif dan menggunakan metode studi kasus. Teknik pengumpulan data menggunakan observasi langsung di lapangan. Berdasarkan hasil, penelitian ini menemukan bahwa prosedur pembiayaan di BMT Almaun Berkah Madani menggunakan dana pembiayaan qardhul hasan. Nasabah mendapatkan dana qardhul hasan sebesar jumlah hutangnya kepada rentenir. Dengan sistem tersebut, nasabah menempatkan jaminan pada salah satu aset yang dimiliki, membayar angsuran pokok kepada BMT, dan wajib menjadi anggota BMT. Dengan demikian, peran BMT dengan produkproduk pembiayaannya memiliki pengaruh yang signifikan pada peningkatan kesejahteraan orang-orang yang memiliki keterbatasan keuangan dan membantu meringankan hutang kepada rentenir.

7. Implementasi Strategi Baitul Maal Wa Tamwil (BMT) Dalam Mengurangi Dampak Negatif Praktik Rentenir (Studi Kasus di BMT Al-Kahfi Jombang) (Islamiyah 2020)

Dana keberuntungan termasuk masalah yang biasa terjadi pada masyarakat menengah ke bawah menyebabkan sebagian masyarakat meminjam uang dari rentenir. Hadirnya BMT Al-Kahfi Jombang sebagai lembaga keuangan mikro yang diarahkan pada masyarakat menengah ke bawah menjadi alternatif bagi masyarakat untuk menghindari praktik rentenir. Metode penelitian yang digunakan kualitatif dengan analisis deskriptif melalui pendekatan fenomenologi pada objek penelitian. Teknik pengumpulan data menggunakan wawancara, observasi, dan dokumentasi. Hasil penelitian ini menunjukkan bahwa praktik rentenir di Pasar Legi Jombang terdapat dua jenis rentenir dengan KSP dan swasta, dengan efek negatif yang ditimbulkan antara lain antara penyebaran praktik riba dan penghambat pertumbuhan ekonomi masyarakat khususnya pedagang kecil, sedangkan strategi pelaksanaan BMT Al-Kahfi Jombang dalam mengurangi pengaruh negatif rentenir yang mengarah pada strategi pemasaran

\section{Analisis Kecukupan Modal Kerja Dalam}


Sistem Tanggung Renteng Pada Ksu Setia Budi Wanita Malang (Yofa Faridah Wulansari 2012)

Dana yang digunakan untuk menjalankan aktivitas operasional sehari-hari disebut modal kerja. Modal kerja diharapkan dapat dikembalikan secara tunai kepada perusahaan dalam jangka waktu tertentu melalui penjualan jasa produksi dan pendapatan. Dalam sebuah Koperasi juga dibutuhkan modal kerja yang optimal untuk memaksimalkan profitabilitas. Penelitian ini bertujuan untuk mengukur tingkat kecukupan modal kerja dalam meningkatkan profitabilitas koperasi dalam pelaksanaan tanggung jawab bersama. Jenis penelitian yang digunakan adalah pendekatan deskriptif kualitatif, yang selanjutnya disebut penelitian kualitatif deskriptif yaitu dengan melakukan wawancara kepada pengurus Koperasi dan menganalisis laporan keuangan. Penelitian ini dilakukan di Koperasi Setia Budi Wanita Malang. Hasil penelitian menunjukkan bahwa modal kerja yang dimiliki SBW koperasi belum sepenuhnya optimal dalam meningkatkan profitabilitas. Hal ini terlihat dari rasio GPM dan ROA yang menurun. Namun jika dilihat dari rasio ROE, koperasi sudah mampu memaksimalkan pendapatan jasa dan penjualan untuk melunasi hutangnya.

9. Penerapan Tanggung Renteng Pada Kelompok Simpan Pinjam Perempuan (Studi Kasus Upk Dapm Kecamatan Padakembang Kabupaten Tasikmalaya) (Ramdani 2018)

Penerapan tanggung jawab saham merupakan salah satu upaya untuk meminimalisir terjadinya kredit macet dalam pengelolaan pinjaman dana bergulir pada Unit Pengelola Kegiatan Kecamatan Padakembang. Tanggung jawab berbagi tidak dapat berjalan tanpa partisipasi anggota kelompok, tingkat partisipasi akan menentukan penerapan tanggung jawab bersama berjalan atau tidak. Penelitian ini merupakan penelitian deskriptif dengan pendekatan kualitatif. Teknik pengumpulan data menggunakan dua sumber yaitu sumber primer dan sumber sekunder, sumber primer diperoleh melalui wawancara dengan sumber dan sumber sekunder diperoleh melalui laporan keuangan dan laporan kemajuan pinjaman. Hasil penelitian menunjukkan bahwa penerapan tanggung jawab bagi hasil pada Unit Pengelola Kegiatan Kecamatan Padakembang telah ditandai dengan baik dengan surat kesediaan untuk berbagi tanggung jawab, pencantuman jaminan berupa penyerahan dan adanya simpanan kelompok sebesar $10 \%$. pinjaman yang spesimen tanda tangannya melibatkan manajemen sebagai kontrol atas tabungan ini. Dalam hal partisipasi anggota kelompok dalam penyertaan modal dan pemanfaatan jasa usaha yang baik, modal sosial dikembangkan dalam penyaringan calon anggota dan pemanfaatan jasa usaha walaupun belum pada kelompok. Akses pinjaman anggota kelompok ke Unit Pengelola Kegiatan di Kecamatan Padakembang sudah mencapai $100 \%$. Kesimpulan dari penelitian ini menunjukkan bahwa pelaksanaan pembagian tanggung jawab di Unit Pengelola Kegiatan di Kecamatan Padakembang cenderung formalitas, hal ini terjadi karena kelompok yang muncul bukan karena ikatan pemersatu tetapi lebih pada upaya untuk mengakses pinjaman. Hal yang berbeda ditemukan pada partisipasi anggotanya yang antusias dalam hal partisipasi padahal partisipasi di bidang organisasi masih lemah karena belum adanya aturan kelompok.

\section{METODELOGI PENELITIAN}

Ditinjau dari hasilnya, penelitian ini adalah penelitian kualitatif, karena penelitian 
ini menghasilkan data deskriptif yang berbentuk tulisan tentang orang atau kata-kata orang dan perilakunya yang tampak dan kelihatan. Penggunaan metode ini dipandang sebagai prosedur penelitian yang diharapkan dapat menghasilkan data deskriptif berupa kata-kata tertulis atau lisan dari sejumlah orang dan perilaku yang diamati (Yarmunida and Wulandari 2018).

Metode penelitian kualitatif sering disebut metode penelitian naturalistik karena penelitiannya dilakukan pada kondisi yang alamiah (natural setting); disebut juga sebagai metode etnographi, karena pada awalnya metode ini lebih banyak digunakan untuk penelitian bidang antropologi budaya; disebut sebagai metode kualitatif karena data yang terkumpul dan analisisnya lebih bersifat kualitatif (Sugiyono 2013).

Arikunto dalam bukunya yang berjudul "Prosedur penelitian suatu pendekatan praktek" menjelaskan bahwa jika penelitian yang mengumpulkan data dan penafsiran hasilnya tidak menggunakan angka, maka penelitian tersebut dinamakan penelitian kualitatif. Meskipun demikian, bukan berarti bahwa dalam penelitian kualitatif tidak diperbolehkan menggunakan angka. Dalam hal tersebut bisa menggunakan angka seperti menggambarkan kondisi suatu keluarga (menyebutkan jumlah anggota keluarga, menyebutkan biaya belanja sehari - hari, dan sebagainya) tentu saja bisa. Yang tidak diperbolehkan menggunakan angka dalam hal ini adalah jika dalam pengumpulan dan penafsiran datanya menggunakan rumus rumus statistic (Arikunto 2002).

Berdasarkan pengertian diatas, dapat disimpulkan bahwa jika pengumpulan data penelitian ini tidak menggunakan angka maka penelitian tersebut dinamakan penelitian kualitatif. Jadi jenis penelitian yang digunakan dalam penulisan ini merupakan penelitian kualitatif deskriptif karena data yang diperoleh dalam penelitian ini adalah berupa gambaran, gejala dan fenomena yang terjadi.

Dengan demikian karena jenis datanya hanya berupa gambaran, gejala, dan fenomena yang terjadi. Yaitu tentang gambaran, gejala dan fenomena yang terjadi di Desa Cilalawi Kecamatan Sukatani Kabupaten Purwakarta mengenai faktor-faktor apa saja yang mempengaruhi masyarakat dalam meminjam pada Bank Emok.

Dalam suatu penelitian pasti ada proses pengumpulan data dengan menggunakan teknik - teknik pengumpulan data tertentu yang disesuaikan dengan kerakteristik penelitian yang sedang dilakukan. Menurut Sugiyono "metode pengumpulan data adalah cara yang dapat digunakan oleh peneliti untuk mengumpulkan data" (Sugiyono 2013).

Dalam penelitian kualitatif teknik sampling yang sering digunakan adalah purposive sampling dan snowball sampling. Purposive sampling adalah teknik pengambilan sampel sumber data dengan pertimbangan tertentu. Perkembangan tertentu ini misalnya orang tersebut yang dianggap tahu tentang apa yang kita harapkan atau mungkin dia sebagai penguasa sehingga akan memudahkan peneliti menjelajahi obyek atau situasi yang diteliti. Atau dengan kata lain pengambilan sampel diambil berdasarkan kebutuhan penelitian. Snowball sampling adalah teknik pengambilan sampel sumber data yang pada awalnya jumlahnya sedikit tersebut belum mampu memberikan data yang lengkap, maka harus mencari orang lain yang dapat digunakan sebagai sumber data (Sugiyono 2015).

Sedangkan instrumen adalah alat yang digunakan untuk mendapatkan informasi tentang karakteristik variabel yang melekat pada unit pengamatan dengan cara sistematis. Pada dasarnya ada tiga metode pengumpulan data yang biasa digunakan dalam penelitian 
kualitatif yaitu: wawancara, observasi, dan dokumentasi.

\section{HASIL DAN PEMBAHASAN}

A. Antusiasme Masyarakat Muslim Di Kampung Cilalawi Desa Cilalawi Kecamatan Sukatani Kabupaten Purwakarta terhadap keberadaan "Bank Emok"

Masyarakat Desa Cilalawi Kec. Sukatani Kabupaten Purwakarta sudah tidak asing lagi dengan transaksi dana pemberian pinjaman modal usaha yang dikelola "Bank Emok". Hal ini sudah berlangsung lama dan sudah menjadi tradisi bagi masyarakat Desa Cilalawi. Setiap Bank Emok memberikan jumlah pinjaman dan sistem yang berbedabeda. Ada yang pada awal pinjaman memberikan Rp. 1.500 .000 dipotong tabungan Rp. 200.000, ada juga yang memberikan pinjaman pertama sebesar Rp. 3.000.000 tanpa potongan. Sistem pembayaran dilakukan satu minggu sekali dengan hari yang berbeda-beda.

Bank Emok adalah orang yang memberi pinjaman uang tidak resmi atau resmi dengan bunga tinggi. Biasanya pinjaman ini tidak diberikan melalui badan resmi, misalnya bank dan bila tidak dibayar akan dipermalukan atau ditagi dengan cara kekerasan.

Menurut Kepala Dinas UMKM, Koperasi, Perdagangan, dan Perindustrian Kabupaten Purwakarta Karliati Juanda, bahwa Pemerintah Kabupaten Purwakarta telah mengeluarkan Surat Edaran terkait keberadaan 'Bank Emok' yang saat ini sedang marak ditengah masyarakat khususnya di wilayah Kabupaten Purwakarta. Yang jelas praktek Bank Emok itu sangat merugikan masyarakat dan ilega keberadaannya. Bank Emok itu pola kerjanya tidak sama dengan Koperasi. Artinya modal Bank Emok itu berasal dari kantong pribadi dan tidak terdaftar dalam keanggotaan di Dinas UMKM, Koperasi, Perdagangan, dan Perindustrian Kabupaten Purwakarta.

Pihak Dinas sudah mensosialisasikan edaran yang ditanda tangani oleh Bupati Purwakarta. Dimana dalam Surat Edaran tersebut melarang segala praktek Bank Emok di masyarakat yang dianggap merugikan. Kalau Bank Emok terdaftar resmi keanggotaanya, kita bisa melacak. Tetapi karena ini tidak jelas maka sangat sulit dilacak. Yang namanya lembaga Koperasi itu tidak bisa sembarangan memberi pinjaman kepada pihak luar masyarakat, kecuali kepada angggota sendiri yang tercatat dalam kepengurusan dan ada rapat kerjanya juga. Kita berharap kepada masyarakat untuk lebih berhati-hati dalam mengambil keputusan, apabila ada tawaran pinjaman uang yang bukan berasal dari lembaga resmi,"pungkas Karliati.

Berdasarkan hasil wawancara dengan Kepala desa Cilalawi menyebutkan bahwa

"Saat ini Bank Emok yang beroperasi di desa Cilalawi sudah lebih dari sepuluh, itu yang melapor ke kantor desa. Akan tetapi yang ada di lapangan kemungkinan lebih banyak, karena menurut warga desa, ada beberapa petugas Bank Emok yang tidak melapor ke kantor desa.

Keberadaan Bank Emok di Desa Cilalawi sudah berlangsung lama. Menurut beberapa warga masyarakat yang diwawancarai penulis menyebutkan bahwa Bank Emok sudah ada sepuluh tahun, bahkan ada yang mengatakan lebih dari sepuluh tahun.

Jumlah Bank Emok yang semakin banyak tidak terlepas dari antusiasme masyarakat dalam menggunakan jasa Bank Emok. Rata-rata dalam satu Bank Emok memiliki jumlah nasabah lebih dari sepuluh orang bahkan ada yang sampai 40 
orang. Antusiasme masyarakat juga terlihat dari jumlah Bank Emok yang dipinjam. Sebagian besar masyarakat meminjam lebih dari satu Bank Emok bahkan ada yang sampai empat Bank Emok sekaligus.

Menurut beberapa warga bahwa pada awalnya mereka berhubungan dengan Bank Emok karena terdesak untuk mencukupi kebutuhan hidup karena mata pencaharian mereka yang tidak tetap dan hanya sebagai buruh tambang yang kadang-kadang penghasilannya tidak mencukupi kebutuhan hidup.

Bank Emok dinilai oleh sebagian warga sangat positif, pasalnya karena praktik dana pemberian pinjaman modal usaha yang dikelola oleh Bank Emok tersebut bisa membantu usaha kecil masyarakat. Model peminjaman nya yaitu dengan cara berkelompok, seperti contoh dalam satu kelompok tersebut terdiri dari 5 orang, peminjaman bisa dilakukan apabila kelompok tersebut sudah ada 5 orang, maka kelompok tersebut harus mencari satu anggota lagi agar kelompok lengkap dan salah satu dari mereka menjadi ketuanya.

Model pembiayaan berkelompok ini sangat membantu bagi kelompok masyarakat yang tidak dapat berhubunngan dengan lembaga keungan formal (un bankable). Model seperti ini diadopsi dari pinjaman kelompok grameen bank. Grameen Bank sebuah bank rakyat pedesaan di bangladesh yang didirikan oleh Mohammad Yunus seorang profesor ekonomi. Pola yang dijalankan dalam praktik tersebut ialah dengan sistem "Kelompok Tanggung Renteng". Sistem kelompok tanggung renteng merupakan pola pengembalian dimana anggota akan saling menanggung/ membantu anggota lain yang kesulitan saat waktu pengembalian. Pola seperti ini memang cukup bagus, karena bisa mendidik tanggung jawab dan kesadaran setiap anggota kelompok dengan saling mengingatkan, setiap mingguan berkumpul semua kelompok.

Dengan begitu Bank Emok bisa mengontrol perguliran dananya secara efektif, dan mampu menekan tingkat kemacetan angsuran pengembalian pinjaman. Semua sistem yang diterapkan oleh Bank Emok dapat berjalan mulus dikarenakan keseriusan setiap anggota digembleng setiap minggu. Namun, merajalelanya Bank Emok ini dianggap meresahkan warga karena menjadikan matinya produk dana pinjaman yang dikelola oleh desa lewat Badan Usaha Milik Desa (BUMDes) karena mereka lebih memilih Bank Emok daripada BUMDes disebabkan oleh mudahnya persyaratan di Bank Emok daripada di BUMDes.

Bahkan, mereka lebih memilih Bank Emok daripada Lembaga Keuangan konvensional maupun syariah. Selain itu, Bank Emok dianggap meresahkan karena yang awalnya membantu, namun ketika pengembalian sangat mencekik warga yang ikut pembiayaan tersebut, disebabkan oleh tingginya bunga (riba) saat pengembalian. Bunga yang dibebankan kepada masyarakat lebih dari $20 \%$. Oleh karena itu, masyarakat yang menerima pinjaman tersebut merasakan kesulitan ketika mengembalikannya.

Sudah jelas dalam ekonomi Islam salah satu cara yang dilarang untuk memiliki harta yaitu dengan cara riba. Itu tidak lain karena riba sebagai suatu tindakan memakan harta orang lain tanpa jerih payah dan resiko, kemudahan yang diperoleh orang kaya diatas kepedihan dan kesedihan orang miskin, serta merusak semangat manusia untuk bekerja mencari uang (Azazy 2015). Dari sinilah, ada ketidak-sesuaian dengan prinsif-prinsif fikih muamalah yang salah satunya mengharamkan praktik yang mengandung riba, apalagi jika melihat dari praktik ini, tambahan dalam pengembalian modal begitu sangat tinggi 
yang mengakibatkan orang kesulitan disaat mengembalikannya.

\section{B. Faktor-faktor apa saja yang mempengaruhi masyarakat muslim di Kampung Cilalawi Desa Cilalawi Kecamatan Sukatani Kabupaten Purwakarta mengguna $\neg$ kan jasa "Bank Emok".}

Pilihan masyarakat desa Cilalawi dalam menggunakan jasa Bank Emok selama ini dipengaruhi oleh beberapa faktor. Faktorfaktor yang mempengaruhinya dapat dilihat dari segi eksternal dan internal. Faktor eksternal adalah faktor-faktor yang berasal dari lingkungan eksternal individu yang sangat berpengaruh terhadap perilaku masyarakat. Yang termasuk faktor eksternal adalah budaya, sosial, dan pemasaran.

\section{Faktor Budaya}

Pada setiap kelompok masyarakat pasti memiliki budaya, dimana budaya tersebut bisa digunakan sebagai aturan, kebiasaan dan ciri khas dari suatu kelompok masyarakat. Faktor budaya terdiri dari budaya meliputi, sub budaya dan kelas sosial merupakan hal yang sangat penting dalam perilaku masyarakat.

a. Sub Budaya

Budaya adalah kumpulan nilai-nilai dasar, persepsi, keinginan dan perilaku yang dipelajari dari anggota suatu masyarakat dari keluarga dan lembaga penting lainnya. Setiap kebudayaan mengandung sub-kebudayaan yang lebih kecil atau kelompok orang-orang yang mempunyai sistem nilai yang sama berdasarkan pengalaman dan situasi kehidupan yang sama. Sub kebudayaan meliputi kewarganegaraan, agama, kelompok ras dan daerah geografis. Pada sisi ini terlihat bahwa masyarakat desa Cilalawi memiliki pengalaman dan situasi kehidupan yang sama. Sebagian besar penduduk yang bermata pencaharian sebagai buruh kasar dan memiliki penghasilan yang tidak tetap menjadikan mereka menggunakan jasa Bank Emok untuk memenuhi kebutuhan hidup mereka.

b. Kelas Sosial

Adalah bagian-bagian yang relatif homogen dan tetap dalam suatu masyarakat yang tersusun secara hirarki dan anggotaanggotanya memiliki tata nilai, minat dan perilaku serupa (Kotler and Amstrong 2007). Masyarakat desa Cilalawi memiliki pekerjaan yang hampir sama karena sebagian besar bekerja sebagai buruh kasar sehingga memiliki pendapatan yang hampir sama. Dengan demikian mereka memiliki kondisi kehidupan yang serupa. Berdasarkan kondisi tersebut maka mereka terbentuk dalam kelompok atau kelas sosial yang sama sehingga mereka menggunakan jasa Bank Emok. Dengan harapan mereka dapat menutupi segala kebutuhan hidup keluarganya denagn menggunakan jasa Bank Emok. Kelompok yang terbentuk terdiri dari beberapa keluarga.

\section{Faktor Sosial}

Selain faktor budaya, pilihan masyarakat desa Cilalawi tersebut dipengaruhi oleh beberapa faktor sosial, antara lain :

a. Kelompok Acuan

Perilaku masyarakat umumnya dipengaruhi oleh individu lainnya, individu yang mempengaruhi tersebut dapat dimasukkan sebagai kelompok primer yang terdiri atas kelompok terdekat dari individu tersebut. Misalnya ; keluarga, teman dan tetangga, sedangkan kelompok kedua adalah kelompok sekunder yang mempunyai interaksi yang lebih formal dan memiliki sedikit interaksi. Kelompok sekunder meliputi kelompok keagamaan, serikat buruh. Pada masyarakat desa Cilalawi yang sudah terbentuk kelas-kelas sosial maka akan dapat dengan mudah dibentuk kelompok-kelompok yang menjadi acuan dalam mengajukan dan menggunakan jasa Bank Emok. Apalagi didukung dengan sistem yang dibuat oleh 
Bank Emok bahwa setiap warga harus terdiri dari beberapa orang yang tergabung dalam kelompok.

b. Keluarga

Keluarga adalah kelompok yang terdiri dari dua atau lebih orang yang berhubungan melalui darah, perkawinan ataupun adopsi dan tinggal bersama. Anggota keluarga sangat mempengaruhi dalam pengambilan keputusan pembelian terhadap individu, keluarga mempunyai peran penting dimana setiap anggota keluarga saling mempengaruhi. Keluarga juga memiliki peran penting dalam pengambilan keputusan untuk menggunakan jasa Bank Emok. Adanya ijin dari suami, maka istri dapat mengajukan pinjaman kepada Bank Emok.

c. Peran dan Status

Dalam kehidupan bermasyarakat, peran dan status selalu mengikuti perjalanan setiap individu. Peran dan status seorang individu dalam kelompok tertentu misalnya keluarga sangat mempengaruhi individu tersebut dalam perilaku pembelian (Kotler and Amstrong 2007). Dalam masyarakat desa Cilalawi terdapat ada beberapa warga yang dianggap memiliki pengaruh terhadap warga yang lain. Dengan hal tersebut maka warga tersebut dapat mengajak warga lainnya untuk menggunakan jasa Bank Emok.

3. Faktor Pemasaran

a. Produk

Produk adalah segala sesuatu yang dapat ditawarkan ke pasar untuk memenuhi kebutuhan dan keinginan konsumen. Pengertian produk secara umum juga dikemukakan oleh beberapa para ahli. Menurut Philip Kotler produk adalah segala sesuatu yang bisa ditawarkan kepada sebuah pasar agar diperhatikan, diminta, dipakai, atau dikonsumsi sehingga memuaskan keinginan atau kebutuhan. Pada faktor ini produk yang ditawarkan oleh Bank Emok sesuai dengan harapan masyarakat. Karena masyarakat membutuhkan uang untuk memenuhi kebutuhan hidupnya. Produk yang ditawarkan oleh Bank Emok akan dapat dengan mudah diterima oleh masyarakat desa Cilalawi.

b. Pemasaran

Pemasaran adalah keinginan manusia yang bertujuan untuk memuaskan kebutuhan dan keinginan langganan melalui proses pertukaran dan pihak-pihak yang berkepentingan dengan perusahaan. Pemasaran adalah kegiatan perusahaan dalam membuat rencana, menentukan harga, promosi, serta mendistribusikan barang dan jasa. Dalam memasarkan produk/jasanya, Bank Emok tidak perlu menggunakan teknik pemasaran yang kompleks. Pemasaran dilakukan oleh beberapa tenaga pemasaran untuk menawarkan kepada masyarakat desa Cilalawi mengenai jasa Bank Emok.

\section{c. Promosi}

Promosi adalah semua jenis kegiatan pemasaran yang ditujukan untuk mendorong permintaan konsumen atas produk yang ditawarkan produsen atau penjual. Tujuan promosi adalah

1) Memodifikasi tingkah laku konsumen,

2) Memberitahukan/menginformasikan produk kepada konsumen,

3) Membujuk dan memotivasi konsumen agar mau membeli produk yang ditawarkan, dan

4) Mengingatkan konsumen tentang produk agar tidak beralih ke produk lain. Promosi dalam sistem ekonomi syariah harus memperhatikan nilai-nilai kejujuran dan menjauhi penipuan. Media atau sarana dan metode yang digunakan harus sesuai dengan pinsip Syariah (Suryani 2008).

Sedangkan dari faktor internal adalah faktor-faktor yang berasal dari lingkungan internal berpengaruh terhadap perilaku masyarakat terdiri dari :

1. Faktor Pribadi 
Dalam perilaku pembelian, faktor pribadi juga memengaruhi seorang individu. Faktor tersebut terdiri dari:

a. Usia

Dalam kehidupan, perjalanan usia tidak dapat dihindarkan. Dengan berjalannya usia maka terjadi perubahan pola konsumsi masing-masing usia. Rata-rata usia pengguna jasa Bank Emok masih tergolong usia produktif atau usia kerja sekitar 30 - 40 tahun. Pada usia demikian dengan dituntut adanya kebutuhan maka mereka menggunakan jasa Bank Emok.

\section{b. Pekerjaan}

Pekerjaan juga dapat memengaruhi seorang individu dalam perilaku konsumsinya, misalkan seorang pekerja kasar maka akan cenderung membeli pakaian untuk pekerjaan kasar, sedangkan pekerja kantoran akan cenderung untuk membeli stelan kemeja atau jas. Dengan kondisi masyarakat Desa Cilalawi yang sebagian besar bekerja sebagai buruh kasar, serta memiliki penghasilan yang tidak tetap maka mereka menggunakan jasa Bank Emok untuk mencukupi kebutuhan hidupnya.

\section{c. Situasi Ekonomi}

Dalam perilaku pembelian, sedikit banyak juga dipengaruhi oleh situasi ekonomi, dengan berubahnya situasi ekonomi maka biasanya akan merubah perilaku masyarakat dalam melakukan pembelian. Dengan memiliki pendapatan yang tidak tetap membuat situasi ekonomi masyarakat Desa Cilalawi menjadi sulit. Mereka kesulitan dalam memenuhi kebutuhan hidupnya. Berdasarkan kondisi demikian adanya Bank Emok membuat mereka menjadi tertarik untuk menggunakan jasa Bank Emok.

d. Gaya Hidup

Individu dengan latar belakang gaya hidup yang berbeda memiliki kecenderungan berbeda pula dalam perilaku pembeliannya. Gaya hidup dapat dipengaruhi oleh keluarga, situasi pekerjaan, hobi, dan yang lainnya. Gaya hidup pada prinsipnya adalah cara seseorang menghabiskan waktu dan uangnya (Yuniarti 2015). Selain faktor ekonomi, alasan masyarakat desa Cilalawi dalam menggunakan jasa Bank Emok juga ada karena gaya hidup. Sebenarnya mereka kondisi ekonominya sudah cukup, akan tetapi karena ingin memiliki gaya hidup yang berbeda maka mereka menggunakan jasa Bank Emok.

\section{e. Kepribadian dan Konsep Diri}

Kepribadian adalah karakteristik psikologis yang berbeda dari seseorang yang menyebabkan tanggapan yang relatif konsisten dan tetap terhadap lingkungannya. kepribadian dapat menjadi variabel yang sangat berguna dalam menganalisis perilaku masyarakat, asalkan jenis kepribadian tersebut dapat diklasifikasikan dengan akurat dan terdapat korelasi yang kuat antara jenis kepribadian tertentu dengan pilihan produk atau merek. Yang juga berkaitan dengan kepribadian adalah konsep diri seseorang. Konsep diri adalah cara pandang konsumen terhadap dirinya sendiri. Dengan mengetahui konsep diri seseorang pemasar akan mengetahui tujuan pembelian bagi konsumen.

2. Faktor Psikologis

Faktor psikologis adalah salah satu faktor yang cukup dominan dalam menentukan proses keputusan pembelian, sebab pola konsumsi seseorang juga dipengaruhi oleh daur hidup keluarga dan kepribadiannya. Faktor psikologis mencakup persepsi, motivasi, pembelajaran, sikap dan kepribadian. Sikap dan kepercayaan merupakan faktor psikologis yang mempengaruhi keputusan pembelian konsumen. Pilihan pembelian seseorang dipengaruhi oleh empat faktor psikologis utama (Etta and Sopiah 2013):

a. Motivasi

Seorang individu dalam kehidupan 
bermasyarakat juga memerlukan motivasi untuk menjalani hidupnya, motivasi sendiri juga dapat mempengaruhi seorang individu dalam melakukan perilaku pembelian. Sebagian besar masyarakat memiliki motivasi untuk menggunakan jasa Bank Emok. Hal ini didorong dari kondisi ekonomi keluarga serta kondisi kehidupan masyarakat di sekitarnya. Meskipun motivasi setiap warga berbedabeda akan tetapi hal tersebut tetap menjadi pendorong dalam menggunakan jasa Bank Emok.

b. Persepsi

Setiap hari individu mempunyai motivasi untuk melakukan pembelian, tetapi faktor lain yang mempengaruhi seorang individu tersebut adalah persepsi. Persepsi merupakan rangsangan yang tereliminer, terorganisir dan teranalisa. Sering kali seorang individu dihadapkan pada suatu pilihan, dalam pemilihan suatu barang misalnya, dengan adanya persepsi maka seorang individu dapat memilih sesuai dengan persepsi yang tertanam dalam dirinya. Sebagian besar masyarakat Desa Cilalawi memiliki persepsi bahwa meminjam uang di lembaga keuangan resmi seperti Bank dan Koperasi sangat sulit dan membutuhkan persyaratan yang banyak. Dengan demikian adanya Bank Emok yang memiliki persyaratan yang mudah akan menjadi hal yang menarik bagi masyarakat Desa Cilalawi untuk menggunakan jasa Bank Emok.

\section{c. Proses belajar}

Dalam melakukan tindakan seorang individu tidak lepas dari pembelajaran, perubahan perilaku individu dalam pembelian juga dipengaruhi oleh pengalaman dan pembelajaran dari pembelian sebelumnya. Ahli teori ilmu pengetahuan mengatakan bahwa pengetahuan seseorang dihasilkan melalui suatu proses yang paling mempengaruhi dari dorongan, rangsangan, petunjuk, tanggapan dan penguatan.

\section{d. Keyakinan dan sikap}

Seorang pemasar biasanya memerhatikan keyakinan konsumennya akan produknya, sering kali seorang pemasar harus merubah iklannya untuk membentuk keyakinan individu dalam pemilihan suatu produk (Etta and Sopiah 2013). Para tenaga pemasaran dari Bank Emok memiliki keyakinan bahwa sebagian besar masyarakat Desa Cilalawi membutuhkan uang untuk mencukupi kebutuhan hidupnya karena pendapatan mereka dari bekerja sebagai buruh yang tidak tetap. Untuk itu mereka mengambil sikap untuk menawarkan jasa Bank Emok kepada masyarakat Desa Cilalawi.

\section{PENUTUP}

Jumlah Bank Emok yang semakin banyak tidak terlepas dari antusiasme masyarakat dalam menggunakan jasa Bank Emok. Ratarata dalam satu Bank Emok memiliki jumlah nasabah lebih dari sepuluh orang bahkan ada yang sampai 40 orang. Antusiasme masyarakat Desa Cilalawi yang tinggi menggunakan jasa Bank Emok membuat jumlah Bank Emok semakin bertambah setiap tahunnya.

Pilihan masyarakat desa Cilalawi dalam menggunakan jasa Bank Emok selama ini dipengaruhi oleh beberapa faktor. Faktorfaktor yang mempengaruhinya dapat dilihat dari segi eksternal dan internal. Faktor eksternal adalah faktor-faktor yang berasal dari lingkungan eksternal individu yang sangat berpengaruh terhadap perilaku masyarakat. Yang termasuk faktor eksternal adalah budaya, sosial, dan pemasaran.Sedangkan dari faktor internal adalah faktor-faktor yang berasal dari lingkungan internal berpengaruh terhadap perilaku masyarakat terdiri dari Faktor Pribadi terdiri dari usia, pekerjaan, situasi Ekonomi, Gaya Hidup, Kepribadian dan Konsep Diri. Faktor Psikologis juga menjadi faktor 
mempengaruhi terdiri dari motivasi, persepsi, proses belajar, keyakinan dan sikap.

\section{Saran}

Dengan hasil penelitian tersebut memberikan implikasi bagi kehidupan sosial ekonomi masyarakat Desa Cilalawi. Hal ini perlu ditindaklanjuti oleh pihak terkait agar keadaan tersebut tidak memberikan dampak bagi masyarakat ke arah negatif.

Untuk itu peneliti memberikan saran kepada pihak terkait khususnya kepada :

1. Pemerintah desa Cilalawi hendaknya lebih memperhatikan kondisi masyarakatnya serta memberikan penyuluhan dan bimbingan kepada masyarakat khususnya dalam menghadapi keberadaan Bank Emok.

2. Pemerintah Daerah Kabupaten khususnya Dinas Koperasi hendaknya memberikan penyuluhan keapda masyarakat mengenai koperasi sebagai salah satu lembaga ekonomi resmi yang dapat digunakan masyarakat untuk mengajukan pinjaman.

3. Tokoh masyarakat dan tokoh agama hendaknya memberikan bimbingan bahwa yang dilakukan oleh masyarakat tersebut telah melanggar syariat agama karena mengandung unsur riba dan akan memberatkan kondisi ekonomi keluarga.

4. Peneliti selanjutnya dapat melakukan penelitian lebih lanjut mengenai dampak dari keberadaan Bank Emok di masyarakat Desa Cilalawi dan hal-hal lainnya yang belum dibahas oleh peneliti.

\section{DAFTAR PUSTAKA}

Arikunto, Suharsimi. 2002. Prosedur Penelitian. Jakarta: PT. Rineka Cipta.

Ayogi, Visita Dwi, and Tuti Kurnia. 2015. "Optimalisasi Peran Bmt Dalam Upaya Penghapusan Praktik Rentenir." JURNAL SYARIKAH : JURNAL EKONOMI ISLAM $1, \quad$ no. 1. https://doi.org/10.30997/jsei.v1i1.254.

Az-zarqa, Az-zarqa, and Naning Nur Hidayah. 2018. "Infak Sebagai Program Pengurangan Ketergantungan Masyarakat Terhadap Rentenir (Studi Kasus Pada BAZNAS Kabupaten Ngawi)." Az Zarqa': Jurnal Hukum Bisnis Islam. Vol. 10. http://202.0.92.5/syariah/azzarqa/article/ view/1739.

Azazy, Yusup. 2015. Buku Daras- Tafsir Ayat-Ayat Ekonomi (Tafsir Al-Ayaat AlIqtishadiyah). Bandung: Mizan.

Drasmawita, Fitri, and Sri Herianingrum. 2020. "Pembebasan Nasabah Dari Rentenir Studi Kasus Baitul Maal Wa Tamwil (BMT) Almaun Berkah Madani." Jurnal Ekonomi Syariah Teori Dan Terapan 7, no. 1: 35. https://doi.org/10.20473/vol7iss20201pp 35-49.

Etta, and Sopiah. 2013. Perilaku Konsumen. Yogyakarta: Andi Ofset.

Haryanto, Sindung. 2017. Sosiologi Ekonomi. Jakarta: Ar-Ruzz Media.

Hatta, Moh. 2008. Beberapa Fasal Ekonomi Di Jalan Ekonomi Dan Bank. XIII. Jakarta: Dinas Penerbiatan Balai Pustaka.

Hernawati, Euis, and Nur Hasanah. 2019. "Pengaruh Rasio Utang Terhadap Hasil Pengembalian Investasi Pada Pt Jamkrida Jabar." Eksisbank 3, no. 1: 23-29.

Islamiyah, Nur. 2020. "Implementasi Strategi Baitul Maal Wa Tamwil (BMT) Dalam Mengurangi Dampak Negatif Praktik Rentenir (Studi Kasus Di BMT Al-Kahfi Jombang)." JIES: Journal of Islamic Economics Studies. Vol. 1. https://ejournal.feunhasy.ac.id/jies.

Kotler, Philip, and Gary Amstrong. 2007.

Dasar-Dasar Pemasaran. Jakarta: Pren

EKSISBANK (Ekonomi Syariah dan Bisnis Perbankan), Volume 4, Nomor 2, Desember 2020 
Hallindo.

Novida, Irma, and Dede Dahlan. 2020.

"Faktor-Faktor Yang Mempengaruhi

Masyarakat Berhubungan Dengan

Rentenir." AGHNIYA; Jurnal Ekonomi

Islam.

Vol.

2.

http://journal.umsu.ac.id/index.php/AG

HNIYA/article/view/4837.

Ramdani, Ramdani. 2018. "10. Penerapan

Tanggung Renteng Pada Kelompok

Simpan Pinjam Perempuan (Studi Kasus

Upk Dapm Kecamatan Padakembang

Kabupaten Tasikmalaya)." Jurnal Al

Amwal (Hukum Ekonomi Syariah) 1, no. 1.

Rusydi, Muhammad, and Ismail Rasulong. 2009. "Dampak Kredit Rentenir Terhadap Keuntungan Usaha Pagandeng Sayur Di Kecamatan Pallangga Kabupaten Gowo." BALANCE : Jurnal Ilmu Ekonomi Studi Pembangunan 1, no. 2: 159-67.

Sugiyono. 2013. Metodelogi Penelitian Kuantitatif, Kualitatif Dan $R \& D$. Bandung: Alfabeta.

- 2015. Metode Penelitian Kuantitatif, Kualitatif Dan R\&D. Bandung: Alfabeta.

Suryani, Tatik. 2008. Perilaku Konsumen Implikasi Pada Strategi Pemasaran. Yogyakarta: Graha Ilmu.

Suyanto, Bagong. 2013. Perangkap Kemiskinan, Problem Dan Strategi Pengentasannya Dalam Pembangunan Desa. Yogyakarta: Aditya Media.

Syaifudin, Ahmad, and Marlina Ekawaty. 2019. "Analisis Faktor Eksternal Yang Dipertimbangkan Masyarakat Muslim Pesisir Tuban Untuk Mengunakan Layanan Bank Thithil." IQTISHODUNA 1, no. 1: 17-38. https://doi.org/10.18860/iq.v1i1.5708.
Yarmunida, Miti, and Wulandari Wulandari. 2018. "Penetapan Nisbah Bagi Hasil Pada Akad Kerjasama Pemeliharaan Hewan Ternak Perspektif Ekonomi Syariah." Jurnal BAABU AL-ILMI: Ekonomi Dan Perbankan Syariah 1, no. 1 .

https://doi.org/10.29300/BA.V1I1.851.

Yofa Faridah Wulansari, Meldona. 2012. "Analisis Kecukupan Modal Kerja Dalam Sistem Tanggung Renteng Pada Ksu Setia Budi Wanita Malang." IQTISHODUNA 8, no. 2. https://doi.org/10.18860/iq.v0i0.2133.

Yuniarti, Vinna Sri. 2015. Perilaku Konsumen, Teori Dan Praktik. Bandung: Pustaka Setia.

EKSISBANK (Ekonomi Syariah dan Bisnis Perbankan), Volume 4, Nomor 2, Desember 2020 